\title{
OCCURRENCE AND ALTERNATION OF CYTORHABDOVIRUSES ON WHEAT IN NORTHERN CHINA
}

\section{OCORRÊNCIA E ALTERNÂNCIA DE CYTORHABDOVIRUS EM TRIGO NO NORTE DA CHINA}

\author{
Fei YANG ${ }^{1,2}$; Aihong ZHANG ${ }^{2}$; Xiwang $\mathrm{LI}^{2}$; Liangzhan $\mathrm{HUO}^{2}$; Dianping $\mathrm{DI}^{2} *$; \\ Hongqin $\mathrm{MIAO}^{2} *$
}

1. State Key Laboratory for Biology of Plant Diseases and Insect Pests, Institute of Plant Protection, Chinese Academy of Agricultural Sciences, Beijing 100193, PR China; 2. Plant Protection Institute of Hebei Academy of Agricultural and Forestry Sciences, IPM Center of Hebei Province, Key Laboratory of Integrated Pest Management on Crops in Northern Region of North China, Ministry of Agriculture, Baoding 071000, PR China.*chmrdv@163.com; miao5058345@163.com.

\begin{abstract}
Northern cereal mosaic cytorhabdovirus (NCMV) and Barley yellow striate mosaic cytorhabdovirus (BYSMV) are two of the most important viral pathogens of wheat. Northern China is the main wheatproducing region in the country. Wheat growing regions pertaining to four provinces, located in northern China, were surveyed for occurrence of NCMV and BYSMV during the growing seasons of the years 2010 and 2016. Wheat leaf samples were collected randomly from symptomatic plants displaying stunting, chlorotic stripes or mosaic. Roughly 73 samples were collected in the year 2010 from 13 fields, and 154 samples were collected in 2016 from 41 fields. Samples were tested for the presence of NCMV or BYSMV using multiplex reverse transcription-polymerase chain reaction (mRTPCR). The results suggested that BYSMV (49.32\% in 2010, 82.47\% in 2016) is gradually replacing NCMV (87.67\% in $2010,13.64 \%$ in 2016) and becoming the main cytorhabdovirus in different wheat growing regions in northern China.
\end{abstract}

KEYWORDS: Cytorhabdovirus. Wheat. mRT-PCR. Survey.

\section{INTRODUCTION}

Wheat (Triticum aestivum) is the most widely grown food crop in the world. The production of wheat in China is the largest globally (http://www.fao.org/faostat/en/\#home). Henan, Shandong, Hebei, and Shanxi provinces contribute to nearly $60 \%$ of the production in China.

More than 50 plant viruses are known to infect wheat in nature. Nearly $80 \%$ of these viruses are transmitted by vectors (insects or fungi) (WANG et al., 2010). Wheat viral diseases present a serious hazard that threatens wheat production globally. Northern cereal mosaic cytorhabdovirus (NCMV) is one of the most important viruses of wheat. NCMV occurs mainly in China, Japan and Korea (TORIYAMA, 1986). NCMV has economic implications in wheat by causing wheat rosette stunt disease (WRSD). This virus affected large areas of the Chinese provinces of Shandong and Hebei from 1965 to 1977 (CHUI et al., 1979). Barley yellow striate mosaic cytorhabdovirus (BYSMV) was first isolated from small brown planthoppers $(\mathrm{SBPH}$, Laodelphax striatellus) in Italy (CONTI 1969), and has also been found in Australia, Africa, Asia and South America (GREBER 1982; LOCKHART et al., 1986; IZADPANAH et al., 1991; MAKKOUK et al., 1996; DUMÓN et al., 2011). In Iran, the virus drastically affected the yield in wheat and millet plants (IZADPANAH et al., 1991). In recent years, this virus has been emerging in northern China, posing a threat to the security of wheat production (DI et al., 2016).

NCMV and BYSMV are members of the genus Cytorhabdovirus sharing high similarity in amino acid sequences with each other (YAN et al., 2015). Both viruses are transmitted by SBPH in a persistent manner (SHINKAI 1963; MILNE et al., 1986). They also share a similar host range with 13 species of Poaceae, including wheat, oat (Avena sativa), foxtail millet (Setaria italica), sorghum (Sorghum bicolor) and maize (Zea mays) (CONTI 1980; ZHANG et al., 1981; LIU et al., 1982; RUAN et al., 1982). Wheat plants infected by NCMV or BYSMV show typical stunting, chlorotic stripes or mosaic symptoms on their leaves. No obvious differences can be observed in early symptoms. Wheat is generally infected with one or both viruses in the field.

According to our previous investigations, NCMV was rarely detected in Hebei province; however, BYSMV could be detected at a high frequency (DI et al., 2016). In this study we tested field wheat samples with typical symptoms of virus disease collected from the years 2010 and 2016 in northern China. We contrasted the investigation results in order to clarify the occurrence and alternation of these two cytorhabdoviruses on wheat in northern China. 


\section{MATERIAL AND METHODS}

A survey of viral diseases affecting wheat was conducted during the growing season in 13 and 41 locations of northern China in 2010 and 2016, respectively. Leaf samples were taken from three to seventeen locations from each province (Hebei, Shandong, Henan and Shanxi), with a minimum of three samples per location. A total of 73 and 154 wheat plants were collected in 2010 and 2016, respectively. Wheat leaf samples were collected from symptomatic plants showing stunting, chlorotic stripes or mosaic patterns. The samples were labeled, brought to the laboratory, and were kept at $-70^{\circ} \mathrm{C}$ until use.

Total RNAs were extracted from samples using the RNA isolation system (Cwbio, Beijing, China) according to the manufacturer's instruction. The presence of NCMV and BYSMV were tested using multiplex reverse transcription-polymerase chain reaction (mRT-PCR) with specific primers (Table 1) synthesized by Sangon (Shanghai, China). The mRT-PCR reaction was performed in a $12.5 \mu \mathrm{l}$ mixture containing $6.25 \mu \mathrm{l}$ of $2 \times$ OneStep RT-PCR Buffer, $0.25 \mu \mathrm{l}$ of HiFi-MMLV OneStep RT-PCR Enzyme Mix, $0.125 \mu \mathrm{l}(0.1 \mu \mathrm{M})$ of each primer, $1 \mu \mathrm{l}$ of total RNA template and $4.5 \mu \mathrm{l}$ of RNase-free $\mathrm{ddH}_{2} \mathrm{O}$. The mRT-PCR condition was set at one cycle at $45^{\circ} \mathrm{C}$ for $30 \mathrm{~min}$ and $95^{\circ} \mathrm{C}$ for $5 \mathrm{~min}$, followed by 30 cycles of $94^{\circ} \mathrm{C}$ for $30 \mathrm{~s}, 54^{\circ} \mathrm{C}$ for 30 $\mathrm{s}$, and $65^{\circ} \mathrm{C}$ for $1 \mathrm{~min} 20 \mathrm{~s}$, and a final extension step at $65^{\circ} \mathrm{C}$ for $10 \mathrm{~min}$. The $\mathrm{mRT}$-PCR products were electrophoresed on a 1.8\% TBE agarose gel with Gold View $(5 \mu \mathrm{l} / 100 \mathrm{~mL})$ and observed under UV illumination.

The results of mRT-PCR were recorded and statistical differences among the mean values from the different sampling years and different viruses were analyzed using the statistical package SPSS version 19 (SPSS Inc., Chicago, IL, USA).

Table 1. Primers used in mRT-PCR for simultaneous detection of NCMV and BYSMV.

\begin{tabular}{lllll}
\hline Primer & Nucleotide sequence (5'-3') & $\begin{array}{l}\text { Expected } \\
\text { size (bp) }\end{array}$ & $\begin{array}{l}\text { Virus } \\
\text { species }\end{array}$ & GenBank \\
\hline NCMVF & AAACAGAGCTTCACGGAGACTTGG & 509 & NCMV & GU985153.1 \\
NCMVR & AACACTAACCCTCCCACGTCTGTA & & & \\
BYSMVF & TCCGCAGGTAGACGCCAAGAAG & 254 & BYSMV & FJ665628.1 \\
BYSMVR & CGCAGTCCCAGTCAGAAAGGTG & & & \\
\hline
\end{tabular}

\section{RESULTS AND DISCUSSION}

A total of 13 fields were surveyed in 2010, and 73 leaf samples were collected. As indicated in Table 2, the mRT-PCR results revealed that 64 out of the 73 samples $(88 \%)$ contained NCMV, and 36 out of the 73 samples (49\%) contained BYSMV.

A total of 41 fields were surveyed in 2016, and 154 leaf samples were collected. As indicated in Table 2, the mRT-PCR results revealed that 21 out of the 154 samples (14\%) contained NCMV, and 127 out of 154 samples (82\%) contained BYSMV. Henan and Shanxi provinces had the highest incidences of NCMV in 2010 (100\%), but in 2016 the incidences declined to $57 \%$ (Henan) and $0 \%$ (Shanxi). In contrast, Henan and Shanxi provinces had the lowest incidences of BYSMV in $2010(0 \%)$, but in 2016 these incidences increased to $54 \%$ (Henan) and 80\% (Shanxi) (Table 2).

Between 2010 and 2016, the incidences of BYSMV in Hebei (100\% in 2010, $90 \%$ in 2016) and Shandong ( $72 \%$ in $2010,93 \%$ in 2016) provinces did not change significantly, but the incidences of NCMV were both dramatically decreased (61\% to $5 \%$ in Hebei, $100 \%$ to $5 \%$ in Shandong; Table 2).
Statistically, we observed an extremely significant difference $(P<0.01)$ in the rate of NCMV-infected between 2010 (88\%) and 2016 (14\%), indicating the reduction of this virus on wheat in northern China. There was a statistically significant difference $(P<0.05)$ between the rates of BYSMV-infected (82\%) and NCMV-infected (14\%) in 2016, indicating a replacement of viral disease on wheat in northern China.

In the present study, the occurrence of NCMV and BYSMV on wheat in northern China was investigated. Symptoms of stunting, chlorotic stripes or mosaic patterns were observed in wheat plants in the surveyed areas in both 2010 and 2016. These symptoms were similar to those previously reported from virus-infected wheat plants in other countries (LEE et al., 1977; LOCKHART et al., 1986; IZADPANAH et al., 1991). 
Table 2. Occurrence of NCVM and BYSMV on wheat plants collected from four provinces of northern China in 2010 and 2016.

\begin{tabular}{llllllll}
\hline Province & $\begin{array}{l}\text { Sample } \\
\text { Year }\end{array}$ & $\begin{array}{l}\text { Number } \\
\text { locations }\end{array}$ & NCMV & BYSMV & $\begin{array}{l}\text { Co- } \\
\text { infection } \\
\text { s }\end{array}$ & $\begin{array}{l}\text { NCMV } \\
\text { incidence } \\
(\boldsymbol{\%})\end{array}$ & $\begin{array}{l}\text { BYSMV } \\
\text { incidence } \\
(\boldsymbol{\%})\end{array}$ \\
\hline \multirow{2}{*}{ Hebei } & 2010 & 3 & $23 / 14^{*}$ & $23 / 23$ & 14 & 60.87 & 100.00 \\
& 2016 & 17 & $61 / 3$ & $61 / 55$ & 1 & 4.92 & 90.16 \\
\multirow{3}{*}{ Shandong } & 2010 & 4 & $18 / 18$ & $18 / 13$ & 13 & 100.00 & 72.22 \\
& 2016 & 7 & $40 / 2$ & $40 / 37$ & 0 & 5.00 & 92.50 \\
\multirow{3}{*}{ Henan } & 2010 & 3 & $22 / 22$ & $22 / 0$ & 0 & 100.00 & 0.00 \\
& 2016 & 8 & $28 / 16$ & $28 / 15$ & 3 & 57.14 & 53.57 \\
\multirow{3}{*}{ Shanxi } & 2010 & 3 & $10 / 10$ & $10 / 0$ & 0 & 100.00 & 0.00 \\
& 2016 & 9 & $25 / 0$ & $25 / 20$ & 0 & 0.00 & 80.00 \\
\multirow{3}{*}{ Total } & $\mathbf{2 0 1 0}$ & $\mathbf{1 3}$ & $\mathbf{7 3 / 6 4}$ & $\mathbf{7 3 / 3 6}$ & $\mathbf{2 7}$ & $\mathbf{8 7 . 6 7}$ & $\mathbf{4 9 . 3 2}$ \\
& $\mathbf{2 0 1 6}$ & $\mathbf{4 1}$ & $\mathbf{1 5 4 / 2 1}$ & $\mathbf{1 5 4 / 1 2 7}$ & $\mathbf{4}$ & $\mathbf{1 3 . 6 4}$ & $\mathbf{8 2 . 4 7}$ \\
\hline
\end{tabular}

*: Number of plants tested / infected.

NCMV is one of the most important pathogens of wheat. In China, NCMV was first noted in the Hebei province in 1949 showing a sporadic occurrence. The first epiphytotic of this disease occurred in 1965 in Shandong province, and henceforth it had been frequently reported by several other districts located in the north and northwest parts of China (CHIU et al., 1979). In the 1980s, NCMV occurred in the Lingbei district of Inner Mongolia (YANG et al., 1987). Crop losses ranged from 30,000 to 40,000 tons per year. BYSMV was first reported in China during 2014 (DI et al., 2014). According to our investigation, the infection area of BYSMV gradually expanded (DI et al., 2016).

Previous studies showed that 335 out of the 367 (91\%) wheat samples collected from the north of China in 2010 were infected by NCMV (DUAN et al., 2013). Similarly, in the present study, the average infection rate was $88 \%$ in 2010 ; however, the average infection rate of NCMV decreased to $14 \%$ in 2016; in Hebei, Shandong and Shanxi provinces the rate was less than or equal to $5 \%$. Conversely, BYSMV showed an increase in the average infection rate between 2010 and 2016. This indicates that BYSMV has replaced NCMV as the major virus impacting field wheat in northern China. However, the reason for this replacement is not very clear. This demands further study.

\section{CONCLUSION}

The presence of NCMV and BYSMV in wheat plants of the studied area were confirmed by mRT-PCR methods. The results demonstrate that BYSMV is replacing NCMV as the main cytorhabdovirus in wheat growing areas of northern China.

\section{ACKNOWLEDGEMENTS}

The authors thank to State Key Laboratory for Biology of Plant Diseases and Insect Pests Open Foundation of China (SKLOF201614) Fund, as well as Kong Lingxiao, Ji Lijing and Yan Chong, other personnel for their help during the surveying process and sample collections of the mentioned regions.

RESUMO: O cytorhabdovirus do mosaico do cereal do norte (NCMV) e o cytorhabdovirus do mosaico estriado amarelo da cevada (BYSMV) são dois dos mais importantes patógenos virais do trigo. O norte da China é a principal região produtora de trigo do país. As regiões produtoras de trigo pertencentes a quatro províncias do norte da China foram pesquisadas quanto à ocorrência de NCMV e BYSMV durante as safras dos anos de 2010 e 2016. Amostras de folhas de trigo foram coletadas aleatoriamente de plantas sintomáticas, exibindo listras ou mosaico clorótico com baixo crescimento. Cerca de 73 amostras foram coletadas no ano de 2010 a partir de 13 campos, e 154 amostras foram coletadas em 2016 de 41 campos. As amostras foram testadas quanto à presença de NCMV ou BYSMV usando reação em cadeia da polimerase 
de transcrição reversa multiplex (mRT-PCR). Os resultados sugerem que o BYSMV (49,32\% em 2010, 82,47\% em 2016) está gradualmente substituindo o NCMV (87,67\% em 2010, 13,64\% em 2016) e se tornando o principal cytorhabdovirus em diferentes regiões produtoras de trigo no norte da China.

PALAVRAS-CHAVE: Cytorhabdovirus. Trigo. mRT-PCR. Pesquisa.

\section{REFERENCES}

CHIU, W. F.; YANG, L.; MEI, R. H.; LIN, Z. L.; TSAI, Z. N. Studies on a rosette disease of wheat I distribution, symptoms and losses. Journal of Plant Protection, v. 6, n. 1, p. 11-16, 1979.

http://doi.org/10.13802/j.cnki.zwbhxb.1979.01.002

CONTI, M. Investigation on a bullet-shaped virus of cereals isolated in Italy from planthoppers. Journal of Phytopathology, v. 66, n. 3, p. 275-279, 1969. https://doi.org/10.1111/j.1744-7348.1980.tb03973.x

CONTI, M. Vector relationships and other characteristics of Barley yellow striate mosaic virus (BYSMV). Annals of Applied Biology, v. 95, n. 1, p. 83-92, 1980. https://doi.org/10.1111/j.1744-7348.1980.tb03973.x

DI, D. P.; ZHANG, Y. L.; YAN, C.; YAN, T.; ZHANG, A. H.; YANG, F.; CAO, X. L.; LI, D. W.; LU, Y. G.; WANG, X. B.; MIAO, H. Q. First report of barley yellow striate mosaic virus on wheat in China. Plant Disease, n. 98, p. 1450, 2014. https://doi.org/10.1094/PDIS-06-14-0579-PDN

DI, D. P.; ZHANG, Y. L.; ZHANG, A. H.; YAN, C.; YANG, F.; LU, Y. G.; TIAN, L. Z.; WANG, X. B.; MIAO, H. Q. Identification of a virus transmitted by small brown plant hopper in wheat. Acta Phytopathologica Sinica, v. 46, n. 4, p. 453-460, 2016. https://doi.org/10.13926/j.cnki.apps.2016.04.003

DUAN, X. F.; DI, D. P.; ZHANG, A. H.; MIAO, H. Q. Molecular detection and identification of the pathogen causing wheat rosette stunt disease in the north of China. Acta Phytopatologica Sinica, v. 43, n. 1, p. 91-94, 2013. https://doi.org/10.13926/j.cnki.apps.2013.01.005

DUMÓN, A. D.; ARGÜELLO-CARO, E. B.; ALEMANDRI, M. V.; BAINOTTI, C.; MATTIO, M. F.; RODRÍGUEZ, S. M.; DEL VAS, M.; TRUOL, G. Identification and biological characterization of barley yellow striate mosaic virus (BYSMV): A new wheat disease in Argentina. Tropical Plant Pathology, v. 36, $\mathrm{n}$. 6, p. 374-382, 2011. http://dx.doi.org/10.1590/S1982-56762011000600006

GREBER, R. S. Maize sterile stunt-a delphacid transmitted rhabdovirus disease affecting some maize genotypes in Australia. Australian Journal of Agricultural Research, v. 33, n. 1, p. 13-23, 1982. https://doi.org/10.1071/AR9820013

IZADPANAH, K.; EBRAHIM-NESBAT, F.; AFSHARIFAR, A. R. Barley yellow striate mosaic virus as the cause of a major disease of wheat and millet in Iran. Journal of Phytopathology, v. 131, n. 4, p. 290-296, 1991. https://doi.org/10.1111/j.1439-0434.1991.tb01199.x

LEE, S. H.; EISHIRO, S. Occurrence of Northern cereal mosaic virus in Korea. Korean Journal of Plant Protection, v. 16, n. 2, p. 87-92, 1977.

LIU, H. Y.; CHEN, H. C. Studies on the host plants of wheat rosette stunt virus. Scientia Agricultura Sinica, v. 15, n. 1 , p. $8-13,1982$.

LOCKHART, B. E. L.; EL-MAATAOUI, M.; CARROLL, T. W.; LENNON, A. M.; ZASKE, S. K. Identification of barley yellow striate mosaic virus in Morocco and its field detection by enzyme immune assay. Plant Disease, v. 70, n. 12, p. 1113-1117, 1986. https://doi.org/10.1094/PD-70-1113 
MAKKOUK, K. M.; BERTSCHINGER, L.; CONTI, M.; BOLAY, N.; DUSUNCELI, F. Barley yellow striate mosaic rhabdovirus naturally infects cereal crops in the Anatolian Plateau of Turkey. Journal of Phytopathology, v. 144, n. 7-8, p. 413-415, 1996. https://doi.org/10.1111/j.1439-0434.1996.tb00315.x

MILNE, R. G.; CONTI, M. Barley yellow striate mosaic virus. CMI/AAB Descriptions of Plant Viruses No. 312, 1986. Available at: http://www.dpvweb.net/dpv/showdpv.php?dpvno=312. Accessed on August 23, 2018.

MILNE, R. G.; MASENGA, V.; CONTI, M. Serological relationships between the nucleocapsids of some planthopper-borne rhabdoviruses of cereals. Intervirology, v. 25, n. 2, p. 83-87, 1986.

https://doi.org/10.1159/000149660

RUAN, Y. L.; JIN, D. D.; LIN, R. F. The host range of the wheat rosette disease (NCMV). Acta

Phytopatologica Sinica, v. 12, n. 2, p. 21-24, 1982. https://doi.org/10.13926/j.cnki.apps.1982.02.004

Shinkai, A. Studies on insect transmissions of rice virus diseases in Japan.

Japanese Journal of Phytopathology, v. 28, n. 3, p. 108, 1963. https://doi.org/10.3186/jjphytopath.28.108

TORIYAMA, S. Northern cereal mosaic virus. In: CMI/AAB Descriptions of Plant Viruses no. 322, 1986.

Available at: http://www.dpvweb.net/dpv/showdpv.php?dpvno=322. Accessed on August 23, 2018.

WANG, X. F.; LIU, Y.; HAN, C. G.; WU, Y. F.; ZHAO, Z. H. Present situation and development strategies for the research and control of wheat viral diseases. Plant Protection, v. 36, n. 3, p. 13-19, 2010.

https://doi.org/10.3969/j.issn.0529-1542.2010.03.004

YAN, T.; ZHU, J. R.; DI, D. P.; GAO, Q.; ZHANG, Y. L.; ZHANG, A. H.; YAN, C.; MIAO, H. Q.; WANG, $\mathrm{X}$. B. Characterization of the complete genome of barley yellow striate mosaic virus reveals a nested gene encoding a small hydrophobic protein. Virology, n. 478, p. 112-122, 2015.

https://doi.org/10.1016/j.virol.2014.12.042

ZHANG, S. X.; SHU, X. Z.; ZHOU, G. Z.; FU, C. S.; LI, Z. L.; WANG, L. Y. Preliminary studies on the hosts range of wheat rosette disease caused by northern cereal mosaic virus. Acta Phytopatologica Sinica, v. 11, n. 1, p. 7-10, 1981.s. https://doi.org/10.13926/j.cnki.apps.1981.01.002 